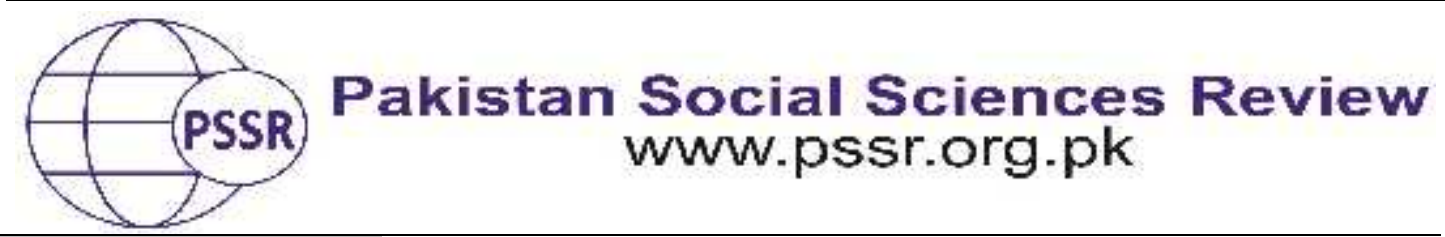

RESEARCH PAPER

\title{
Sufi Practices at the Dargah of Karmanwala Sharif: An Appraisal
}

Nasir Amir ${ }^{1}$ Muhammad Iqbal Chawla ${ }^{2}$

1. Ph. D Scholar, Pakistan Study Centre, University of the Punjab, Lahore, Punjab, Pakistan

2. Dean, Pakistan Study Centre, University of the Punjab, Lahore, Punjab, Pakistan



\section{Introduction}

Sufism is arcane and divine side of Islam reflecting the inward visage of the world's second largest religion. Sufism has the specific faith, which consist of six significant elements of beliefs and agreement: the believe in Allah, His Angels, Messengers, the day of rebirth, high-quality belief on good and bad, and in the end Allah's predestination. The Islamic Sufism defines its basis with life and beloved Prophet`s character of Islam Hazrat Muhammad (S.A.W), who is the distinctive example for all mystics, Sufis, Faqirs, or Darwaish are the persons, who dedicate themselves for virtue. They adopt the path of Haqiqat and Tariqat in brightening the lives of humanity in the light of the teachings of Quran and Sunnah by actualizing the teachings of Islam, as they see them, in their daily lives. In fact, mysticism also depends on five basic principles of Islam i.e. Kalma (Shahadat), the Prayer (Salat), the Soum (Fasting during Ramadan), and Zakat, the obligatory donation towards the poor and performance of pilgrimage (Hajj) if an individual can afford the expenses (Hilal, 2004). 
It is an admitted fact that Sufis relate themselves to the spiritual teaching and thoughts of the beloved Prophet Hazrat Muhammad (S.A.W). Beloved Prophet Muhammad (S.A.W) went from Makkah to Medina and embarked on a campaign against his religious opponents. However, all bases unanimously relate that Messenger of Allah continued to lead an exceedingly austere and simple life. He considered his personal form of Fuqr, which refers to a life of simplicity and resignation to Allah's will. Sufis, as thinkers and philosophers, differed from certain subjects related to the teachings of Islam although they all were agreed upon basic teachings and beliefs of orthodox Muslims (Shahzad, 2014).

Sufism or Tasawwuf is considered an esoteric segment of life. Sufis have resolute belief in the Holy Quran as a foundation of their commitment. The teaching of Holy Quran is perfect and universal. The companions of Muhammad's (S.A.W.) were in the large number of people, who dwelt in Medina-tul-NabiMasjad practicing self-abnegation. They were called Ahle-e-Suffa or Ashab-e-Suffa (The people of Verandah) (Ghosh, \& Mir, 2016).

Islam made salat mandatory, five times a day, and fasting for the whole month of Ramadan, the ninth month of Islamic calendar, compulsory. But AhleSuffa and different pupils of beloved Prophet Muhammad (S.A.W) observed incessant piety and fasting as did the beloved Prophet Muhammad (S.A.W). Tasawwuf penetrate in Islam as in earlier level Taqwa and Zohud was thoroughly used for more Holy people who had renounced the world of materiality. It was after the second century Hiji that the words Sufi and Tasawwuf became well-known among the masses. The Quranic phase entitled Al-Tauba (Repentance) was revealed in 9thHijri and contained a decision of immunity for the idolatrous people, which had many times violated treaties. Moreover, it drew the attention of Muslims to avoid hoarding of wealth. The Sufis believe that the beloved Prophet Muhammad (S.A.W.) declared that every line of Holy Quran has an external and inward domain with quest for Shariat, Haqiqat and Tariqat (Hilal, 2004).

The mystical experience with God, however, finds its expression within the context of man's expressive language, as he is a rational being, and also his community, as he is a relational being. An act of belief is dependent on language which in turn in dependent on community. An act of belief exists in a community of spiritual beings where language is alive. An act of reliance or any religious experience cannot exist without language of expressions.

\section{Analysis and Discussions}

The history of Sufi Dargah is completely parallel to the political history. It was around close to 10 centuries AD that Political changes paved way vast migration of Sufis and establishment of Dargah. In South Asia, there was an intricate relationship between power mechanism and Dargah formation. As a complex social and administrative network Dargah played an inevitable multi-dimension role in the continuing discourse of power. Since long it remained the subject of concern for 
many sultans that was the reason ran parallel to the institution of the sultanate. (Hilal, M. 2004)

Every society has its specific habits and customs regarding its way of life. Dargahs play a vital role in the spiritual connection among Muslims of Pakistan who visit them regularly, asking for Allah's help through the intermediary of the noble person buried there. The word Dargah is derived from Latin practices. Dargah can be viewed from different angles and they fulfill many societal of functions which include social, economic, political, educational, cultural and religious ones. People are deeply devoted to these places and are staunch believers of their chosen Dargahs. They come to these Dargahs seeking succor and support because they believe that Sufis and Saints have direct links with Allah. The most distinctive characteristics of Naqshbandiya order were initiates from beloved Holy Prophet Muhammad (S.A.W) to Abu Bakr-al- Siddiq, a fast friend and staunch follower of beloved Holy Prophet Muhammad (S.A.W) with a physically powerful adherence to Sharia or the Divine Law as propagated by the Holy Prophet. First man of significance in record of Naqshbandiya order is Yousaf Hamadan. In addition given four caliphs, he marked eight principles, or "refined words," that provided a framework for order.

Khwaja Bahauddin Naqshband (1317 A.H to 1389 A.H) was organizer of Naqshbandiyya order. He was born at Kushk-i-Hinduwan which is in the neighborhood of Bukhara in Central Asia, thereafter in his honor the town came to be called Kushk-I-Arifan. The name Naqshband that he utilized refers to an "Embroiderer" or a "Painter" (Ghosh, \& Mir, 2016).

Despite the fact that, it is preposterous to expect to presume that all branches or individuals from Naqshbandiya were politically dynamic since forever of order, intense faith in adherence to Sharia and Sunna and a common demeanor onwards function of Sufis in Islamic culture added to political investment of some Naqashbandi leaders. In late middle age and pre-current periods, it was normal for Naqashbandi pioneers to parley in political questions, fulfill their obligations for the benefit of a populace, demonstration with regards to well-known notion, impact strategy, or control huge parcels of land. In districts of Transoxiana and Khorasan in which Turko Mongols governed over Persian populaces, Naqashbandi leader at regrets assumed function of protecting Sunni Islam against Shiaism and of abnormal impact of Turko Mongol vagrant standard law for Islamic law. Naqshbandiyya silsila picked up followers among both the Turkic and Persian populaces of Central Asia and was pervasive in both metropolitan and rustic regions. However, as it spread in Khorasan, Naqshbandiya was solidly settled in scholarly and social milieu of capital city of Herat, getting a charge out of extraordinary prestige under initiative of Al-Din Kashgari and Abdul Rahman Jami.

A few particular parts of Naqshbandiya had created principle ones being Yasavi, started by Ahmad Yasavi Mujaddidi, set up first in Quite a while one in replacements of Hamadani, Sheikh Ahmad Sirhindi and Khalidi, set up by Mawlana Khalid Baghdadi, last part of Naqashbandi to accomplish ground-breaking obedience all through Muslim world. The Order spread widely in various parts of 
Ottoman Turkey, Kurdistan, Eastern Turkistan, Syria, Palestine, India, focal Asia, Indonesia and Malaya. A significant resurrection of Naqshbandiya request came through administration of Mawlana Khalid Baghdadi who established Khalidi branch which turned out to be especially ground-breaking in Turkey and increment to the extent Malaysia. His concern for the protection of sharia was especially significant during the time when Ottomans confronted rising difficulties from West. The Khalidi Sufi structure spread widely throughout Arab, Turkish, and focal Asia but was ground-breaking in Kurdistan and Anatolia. The tradition of Naqashbandi activity is demonstrated today in the set-up of Naqashbandi families among the Kurds where, over the long run, many in the Kurdish society became politically active such as the Bargains.

In later periods such as for the most part of 19th and 20th centuries Naqshbandiya assumed a function as transforming and hostile to pioneer oppose developments. Among a few models is Sheikh Shamil's defensive struggle against Russian domination in Dagestan in nineteenth century, dynamic participation of Naqshbandiya Mojahedin in Soviet-Afghan war, time of Shah Abdul Aziz is approved development in subcontinent under British government and time of Naqshbandiya drove rivals in China. In spite of the fact that it is hard to discover the degree of Naqashbandi activity in Central Asian states today, its adherents are active in many locales of Dagestan and Fergana valley and the Order's Dargahs are seen as important stops on journey. In other areas of Islamic world Naqshbandiya keeps an after especially in Afghanistan yet additionally in Turkey Kurdish districts of Syria and India, Indonesia and China. Dargah is place having graves of Sufi Holy people. Muslims don't go to sanctuaries and Hindus don't go to mosques, however, both go to Dargahs. Accordingly each Dargah assumes the position of a connecting link between various networks of people where love for humankind is proclaimed. A few Muslims view Dargahs as spots of bidet or love of an icon which is prohibited by Islam. Numerous strict Muslims and Hindus accept that going to a Dargah is just revering the grave of a holy Sufi person, while Islam permits love of just Allah alone. This lone shows silliness and strict radicalism of such individuals. By going to a Dargah one just shows regard and remembrance of the piety and character of a departed Sufi Holy person and it doesn't add up to venerating his grave.

Sufism, which is an inward aspect of Islam and the legitimacy of Sufi's claim of wielding miraculous power, came from the grand tradition of Islam, mainly the life and teachings of Prophet Muhammad (PBUH) (Burckhardt, 1983). Mysticism has been a main ingredient of Islamic theology and through theory and practice the religion of Islam spread throughout the world. The Sufis and their lifestyle, thoughts and actions attracted millions of people who embraced Islam. These Sufis addressed problems of numerous people, including spiritual, economic, social, cultural and anthropological (Chawla, 2015).

The Dargah of Hazrat Karmanwala Sharif is a famous Dargah among Sufi saints in Indo-Pak.It has become a place of peace not only for Muslims but for all 
those people who have affiliation and reverence with his spiritual outlook. The Dargah of Hazrat Karmanwala Sharif provides solution in lifestyle of associated people. The present research will play a part in current literally works of anthropological research on this particular issue. It will also play a part in better knowing of various religious problems, concerning Sufism and traditions and methods performed on Dargah and also their Islamic place and presentation of their religious characteristics and their religious credibility, as indicated by various religious regulators and ways of thinking. The Dargahs help to provide a powerful socio-religious system for the individuals of the area. Thus an anthropological study is the best and most reliable means for revealing the holistic characteristics and importance of Dargah in a neighborhood.

Hazrat Pir Syed Muhammad Ismail Shah Bukhari Hazrat Karmanwala Sahib had five sons and two daughters. One daughter and three sons, Syed Usman Shah Bukhari I, Syed Tayyab Ali Shah Bukhari and Syed Ali Gilani died in childhood. At the time of his death two of his sons, Hazrat Muhammad Ali and Hazrat Usman Ali II were alive. Hazrat Syed Ismail Shah Bukhari (R.A.) was born in 1288 A.H (1884 CE) at Karmunwala village in Farozepur District (India). He belonged to the Naqshbandiya Order and gained his spiritual and religious guidance form Hazrat Main Shair Muhammad Shariqpur Sharif (R.A). Hazrat Syed Ismail Shah Bukhari (R.A) renewed as Karmanwala which derived from Karmunwala a village (Latif, 2010, pg. 8).

The five main postulates of Dargah Hazrat Karmanwala Sharif are: proper faith and belief, character and actions, Preaching of Religion, Teaching and training of Bellies and service of humanity. Hazrat Syed Ismail Shah Bukhari Karmanwala (R.A) mission was continued by his eldest son Syed Muhammad Ali Shah Bukhari Naqashbandi, younger son Syed Usman Ali Shah Bukhari and grandson Syed Guzanfar Ali Shah Bukhari, who are also buried in this Dargah. Syed Sumsam Shah Bukhari and Syed Tayyab Ali Shah Bukhari are also his grandson. The Dargah and main mosque are maintained under authority and supervision of Sajjada Nasheen of Dargah Hazrat Muhammad Ali Shah Bukhari in honor of their late father Hazrat Muhammad Ismail Shah Bukhari (R.A), who was affectionately referred to as "Hazrat Sahib Karmanwala".

Since 1993 Baba Syed Mir Tayyab Ali Shah Bukhari has been the sitting SajjadaNasheen of Dargah Karmanwala Sharif. Pir Syed Sumsam Shah Bukhari (Provincial Minister of Punjab) is an elder brother of Baba jee Mir Tayyab Ali Shah Bukhari. Beside the Dargah of Hazrat Karmanwala, a Karmanwala University has been launched by Syed Mir Tayyab Ali Shah Bukhari, Sajjada Nasheen of Hazrat Karmanwala Sharif. A big mosque, a small hospital, madras for boys and girls, a library, a hall of MehfilZikar, a Langerkhana (place where free food is served) are also part of this Dargah. This is commonly as "Astana Alia Hazrat Karmanwala Sharif". It is located adjacent to the main Lahore-Multan road between Okara and Renala Khurd alongside Hazrat Karmanwala Railway station. Hazrat Karmanwala died on 27th Ramadan (1325 A.H or 20th January 1966 A.D). The Annual Urs of Hazrat Ismail Shah Bukhari Karmanwala is celebrated on 27th to 28th February of 
every year at "Astana Alia Hazrat Karmanwala Sharif". The local government observes a local holiday every year on occasion of the Urs Mubarak. Thousands of followers come from all over the world to participate in the Urs Mubarak and the place is full of hustle and bustle at that time (Latif, 2010, pp. 1-3).

This present study is about all Islamic and spiritual practices which take place at Dargah Hazrat Karmanwala Sharif. Astana Hazrat Karmanwala Sharif has become an essential part of the Muslim community of district Okara. It has created a balance among religious, spiritual and cultural practices. The followers called 'Ballies' (companions) visit the Dargah daily, weekly, monthly and at the time of the annual Urs to participate in ceremonies of Urs. These ceremonies comprise not only religious and spiritual practices but also create a suitable social and economic environment at Dargah Hazrat Karmanwala Sharif. They emerge with faith a simplest way to pay homage to Sufi and riches to big event of annual 'Urs'. Like all other Dargahs in subcontinent, daily and weekly practices are held at Dargah Hazrat Karmanwala Sharif. After the 'Fajar' prayer the Imam delivers a speech which starts with recitation of Holy Quran which is then explained in light of various Hadith. A question and answer session is also held at end of speech during which the Imam not only discusses social, spiritual and economic problems of Ballies but also presents appropriate solutions for them. After this a Mehfil-e-Zikar is held in which zakr-e-jhaari is expounded with all its pros and cons. At the end a Zikar-e-dua is performed with assurance of best acceptance of wishes and desires, etc.

The Ballies shake hands with one another and also discuss their personal matters. Thursday is the most significant and busiest day of week with regards to attendance and practices at Dargah Hazrat Karmanwala Sharif. The area in and around Dargah is full of people on every Thursday. A large number of ballies are gathered at Astana for collective participation in the activities of the Dargah. They recite Drood-o-Salam for their beloved Holy Prophet (S.A.W.) and pay a rich tribute to Hazrat Karmanwala Sharif in a state of ecstasy. The 'Langer' (occasion for free distribution of food) is also open to Ballies. The Sajjada Nasheen of Dargah Hazrat Karmanwala Sharif meets with Ballies and participates in peer and mureed session which is held in this ceremony. He encompasses and makes mureed on behalf of Hazrat Karmanwala Sharif.

After the Issha prayer, a big ceremony of ' $\mathrm{Zikr-o-Fikr'} \mathrm{is} \mathrm{held} \mathrm{that} \mathrm{opens} \mathrm{with}$ recitation from Holy Quran, thousands of Ballies participate in it and after Darood-oSalam to beloved Prophet Muhammad (S.A.W) Mehfil-e-Natt is arranged in the mosque attached to Dargah Hazrat Karmanwala Sharif. NaatKhwan from all over county participates in it. Many religious scholars are also associated with them. They deliver different sermons in light of teachings of Hazrat Karmanwala Sharif. At the end, special dua session is conducted by the khteeb of Larnia Masjad Hazrat Karmanwala Sharif. A large number of Ballies stay the whole night and participate in practices of Astana that will take place in early morning of Friday. The day Friday acquires special attention from devotees of area especially a large number of people 
of Okara city and District Okara go to Dargah Hazrat Karmanwala Sharif to perform Juma prayer. They wear white Kurta Shalwar and turban to perform Juma prayer. It has now become a big event of the week. The Dargah is cleansed thoroughly and the Chadar of grave is changed. At time of Juma prayer, khteeb delivers a comprehensive speech in light of Quran and Sunnah and teachings of Hazrat Karmanwala Sharif. They also advise Ballies (Friends) to follow practices of Hazrat Karmanwala Sharif in their practical lives.

After Juma prayer, some bellies may go back to their homes and some stay up to the Issha prayer. They accommodate each other and share their social, spiritual and economic problems. They also visit Sajjada Nasheen Hazrat Karmanwala Sharif at his residence. After participation in Essha prayer devotees sit in collective dua and then depart to their homes. On 11th day of every lunar month, a khtam of Giarvi Sharif is celebrated in Jamia Masjad Dargah Hazrat Karmanwala Sharif. A Mehfil-eNaat is practiced from Mugrib to Essha prayer. It begins with recitation from Holy Quran and ends with a Khtam Sharif. After sending Drood-o-Slam, tradition of collectively dua is held and sweets are distributed among visitors. Every year on 12th of Rabi-ul-Awal, a Mehfil is arranged in Masjad of Dargah Hazrat Karmanwala Sharif to memorialize the birth of beloved Holy Prophet Muhammad (S.A.W). The Dargah is embellished with colorful buntings, flags and lights. Thousands of people participate in the Mehfil. It starts with the Fajar prayer. Quran khwani is followed by Naat. This Mehfil continues till late at night. Speeches of different scholars are delivered. At end drood-o-slam is recited and Langer is dispersed among Zairian.

The Sufi practice of Sharing Langer has effective social implication on the Punjabi native community in particular. Langer means free public kitchen aiming sharing food with others irrespective of religion, class, color, doctrine, age, gender or social rank (Chawla, 2016). The distribution of Langer has been the hallmark of Naqshbandiyya Sufism since centuries. This free public kitchen at Naqshbandi Dargahs is opened to all and meant to make available food to all devotees and visitors. Aficionados fervently donate to it either by contributing food stuff or by partaking in the cooking and delivery of the food. Thus the concept of Langer is to maintain the norm of impartiality among all people of the globe. Moreover the ritual of Langer articulates the morals of sharing, community, comprehensiveness and unanimity of all human races.(Iqbal, \& Ibrahim, 2017)

On 27th of Rajab-ul-Murjab, a large number of Ballies get together at Dargah of Hazrat Karmanwala Sharif and stay whole night to perform nawafil. In this program a Mehfil-e- Zikar is held after Essha prayer followed by a Mehfil-e-Naat. At end Drood-o-Slam is presented to beloved Holy Prophet (S.A.W). After Dua, Langer is disseminated in Langer khana.

On 15th Shaban-ul-Muazam after Essha prayer, a Mehfil-e-Zikar and Mehfile-Naat is held in Masjad of Dargah Hazrat Karmanwala Sharif. The devotees perform nawafil throughout night. The ceremony ends with dua at midnight. In annual Urs, devotees display different stalls of sweets, toys, clothes, embroidery, prayer mats, caps, prayer beads, etc. At this occasion, different political and religious 
personalities like the Chief Minister, Governor etc., are specially invited and they feel honored to engage in practices performed at the Dargah. TheUrs is started after Fajar prayer with recitation of Holy Quran and Naat Maqbool (S.A.W) and then speeches of different scholars are continued throughout day till night. They express their views on different topics relating to Islam, Islamic mysticism, hadith, fiqha, biographies of prophets and saints.

After Namaz Essha, present Sajjada Nasheen of Dargah, Peer Syed Tayyab Ali Shah, performs special dua with profound tears of devotees. After the khtam, Drood-o-Slam is practiced for the beloved Hazrat Muhammad (S.A.W). Educational practices are in full swing at Dargah Hazrat Karmanwala Sharif. "Hazrat Karmanwala Sharif University" has been established where thousands of students and Ballies are educationally, spiritually, morally and trained in social get-up and interaction. They have spiritual power to establish a relationship between man and society. They believe that physical contact with grave of Sufi opens new doors for material as well as spiritual domains. Organizational committees organize many religious and spiritual meetings in every nook and corner of country. A large number of Ballies go to mosques in rural and urban areas to inspire people to lead life according to teachings of beloved Holy Prophet (S.A.W) and Hazrat Karmanwala Sharif. Every month, a magazine, Mujallah Hazrat Karmanwala Sharif, is published from Dargah under supervision of these organizational committees.

It is believed that soil does not consume the body of a Sufi. It remains intact in the grave after death. So he needs rest for some hours daily. That is the main reason for closing of all shrines at night. For small shrines, this does not matter as usually, after sunset, shrine is closed for Zaireenand there is no one at night time who may visit. But for the popular shrines, where thousand people visit every day, opening and closing of a shrine has taken a form of ceremony. These moments create special impact for Zaireen. The early hours for morning, particularly before sunrise are assumed to be the best for acceptance of supplication prayers, wishes, desires, $d u a$ etc. this time is also assumed to be the time when Sheikh wakes up. So the ceremony for opening of the shrine of Hazrat Ali Hujveri is held daily, almost one hour before Adhan-e-fajr (Shahzad, G. 2014).

Sharia is strictly followed at Dargah Hazrat Karmanwala Sharif. A beardless person or anybody with a short beard is not allowed to say prayer in first row of the jamat prayer. The Ballies have beard according to Sunnah with white turban and shalwar kamez. Mehfil-E-Same is prohibited at Dargah of Hazrat Karmanwala Sharif. The Ballies are also forbidden to take part any musical practice. Taking picture or selfi is considered not a good act at Dargah. The devotees are not permitted to say prayer bare-headed. Wearing turban or caps is compulsory at Dargah.

Present SajjadaNasheen of Dargah Hazrat Karmanwala Sharif, Hazrat Pir Syed Tayyab Ali Shah Bukhari, is a polite and kind-hearted personality who renders services for development of Dargah Hazrat Karmanwala Sharif. Dargah Hazrat 
Karmanwala Sharif is also playing a significant role in social reforms. Various free dispensaries are working in different villages of Okara District. They are providing not only medical assistance but also financial support to down-trodden people of society. Many schools and dine madras (religious schools) have been spreading knowledge of Holy Quran and Sunnah under guidance of Darga hHazrat Karmanwala Sharif which acts as a spiritual guidance for people of Pakistan.

Among different Dargahs of healing, Dargah Hazrat Karmanwala Sharif tops the list and performs functions that can be explained in terms of satisfactory healing methods, which fulfill needs of people. People come to Dargah Hazrat Karmanwala Sharif for various personal reasons such as for curing their illness, to secure birth of a child, others come to avoid curse of a demon, to obtain satisfactory grades in schools or to secure financial success in life. It is from contribution of saint's blessings that satisfaction can be achieved so that personal fulfillment may be gained or regained. Dargah Hazrat Karmanwala Sharif in Pakistan is a complex organization which meets multi-dimensional needs of associated areas. Individuals are greatly dedicated to these locations and are staunch followers of Dargah. They come to Dargah to seek help because they know that Sufis have immediate link with Allah.

Popular Islam has played a fundamental role in the spread of Islam in the subcontinent. Visitation of the popular Dargah is a part of the daily life in the rural setting of the Pakistan. Dargah as a social institution has multifold aspects; it performs certain functions for the pirs and at same time the murid too. The essence of Dargah lies in the beliefs of the visitors and whishes they associate to the Dargahs. Significance of Dargahs portrayed in the belief and obedience of its followers via practices. Overwhelmingly, Dargahs locally accommodate many issues of the masses; especially of those who adhere to it .On the basis of the results shown in this study it can be conclude that practices performed at Dargahs is the product folk wisdom (Khan \& Sajid, 2011).

\section{Conclusion}

The study of Sufism falls in the domain of socio-religious and spiritual history which is, generally, a neglected aspect of history-writing in Pakistan. For the same reasons the Karmanwala Dargah has also been overlooked by the historians so far. This study has been conducted to understand Sufism and Sufi practices in Pakistan by focusing on the Karmawala Shrine. Sufism is considered as a metaphysical element of human life. Sufis base their beliefs and faith upon the Quran and the Sunnah. Dargahs (Shrine) in Pakistan are also places that facilitate social integration, regardless of sect, between the people who reside around the Dargah and others who travel to it from rest of the country. The world is full of sorrows and difficulties for many people; therefore, they go to shrines to get help for their removal and to get comfort from their spiritual leaders. Some of their sorrows are dealt with when they share their personal matters with one another because sorrows and difficulties are lessened when these are shared. The main cause of popularity of Dargahs in Pakistan, particularly of Karmanwala Sharif, is not only 
that it provides food and shelter to needy people but it also services humanity in a general way. It also acts as a socio-religious institution that helps in appropriate performance of religious rituals and ceremonies. Sufis are expected not to focus only on their personal lives but instead regard all of them as belonging to Allah.

In Pakistan, particularly the Dargah of Hazrat Karmanwala Sharif in district Okara, presents religious flexibility and tolerance. There are many functions which are performed at this shrine, for instance Chadarposhi, Naat conference, Qawali, Eid-ul-Melad-u-Nabi, Juma prayer, Eid prayer, Seerat Conference and Mela Chiraghian. All functions which are performed at this Dargah locale are performed under the aegis of the Auqaf department. Urs is also source of economic and social interaction. However, for spiritual solace and health-seeking purposes which come in the form of amulet, Dum Darood, Naqshetc, villagers, majority of them being females, visit Hazoor Babe G (a prestigious religious name) who is the trustee of the Shrine. We can say that for these reasons the Dargah of Karmanwala Sharif is providing the community with langar, shelter, spiritual satisfaction, love and respect irrespective of the caste, creed and gender of its constituents. Thus the Dargah has become a hub of socio-cultural, spiritual and economic activities in an area where the feudal system still has strong roots. 


\section{References}

Chawla, Iqbal, M. (2015).Sufism and Sufi Practices in Pakistan: A Case Study of 'NotanWali Sarkar'. South Asian Studies, Vol. 30, No.1, 7 - 14.

Chawla, Iqbal, Shoeb, R. \& Iftikhar, A. (2016). Female Sufism in Pakistan: A Case Study of Bibi Pak Daman, Pakistan Vision, Vol 18, Issue 1, 224-247

Ghosh, A. K., \& Mir, S. A. (2016).A short introduction to origin, beginning and history of Sufism or Tasawwuf. International Journal of Management and Applied Science Vol 2 Issue 2,75-82

Hilal, M. (2004). Scholars, Power and Politics: Some Aspects of Khanaqah Culture in the Delhi Sultanate. International Review of Humanities and Scientific Research, 31(1-2), 490-503.

Iqbal, T., \& Ibrahim, M. (2017). The Region of Punjab: A Sufi Perspective with Particular Focus on Chishtiya Sufism. Al-Idah, 34(1), 126-134.

Khan, S., \&Sajid, M. R. (2011). The essence of shrines in rural Punjab: A case study of the shrines at Barrillasharif, Gujrat-Pakistan. Humanity and Social Sciences Journal, $6(1), 66-77$.

Latif, A. G. (2010). The Saint of the Century (1st ed.). HazratKarmanwal Publishers, Okara.

Shahzad, G. (2014). From Sufi Thinking to Sufi Shrine.Sang-e-Meel Publications. 